\title{
Contract Law Perspective Mapping To Quality Characteristic of the Government Procurement in Indonesia: Doubt on the Practice of Corruption, Administrative or Civil Violations?
}

\author{
Ahmad Feri Tanjung ${ }^{1}$, P.L. Rika Fatimah ${ }^{2} \&$ Tan Kamello $^{3}$ \\ ${ }^{I}$ Faculty of Law, Universitas Sumatera Utara, Indonesia \\ ${ }^{2}$ Faculty of Economics and Business, Universitas Gadjah Mada, Indonesia \\ ${ }^{3}$ Faculty of Law, Universitas Sumatera Utara, Indonesia
}

\begin{abstract}
Government Procurement Contract is a contract between the government and suppliers. The utilization of state finances in Government Procurement Contract is like a double-edged sword. While necessary for the service to community, it also lies in a corruption-prone area. State apparatus are performing the Government Procurement Contract in good faith, yet overshadowed by a fear of corruption threat in case they slip and inflict losses to the State. This article will address the fear with the explanation that not all violations in the Government Procurement Contract are considered as the acts of corruption; they can also be administrative or civil violations.
\end{abstract}

Keywords: abuse of authority, corruption, procurement contract, public procurement, quality characteristic

\section{Introduction}

The procurement of goods and services is a legal relationship between the government and suppliers. In procurement process in Indonesia, every violation, including errors in the selection of supplier, the execution of contract, or the handover of goods or services, is categorized as criminal acts, while such abuse is better categorized as administrative or civil violations. By adhering to a theory of criminal law, the Ultimum Remedium, in the imposition of sanctions, criminal sanction becomes a last resort with the precedence of civil lawsuit with compensation claims as well as administrative penalties in the procurement of goods and services. Government procurement, in general, refers to the purchase by government bodies from external supplier to run their missions in serving the public (Arrowsmith, 1999) through the establishment of contract - such term, however, can also be used for less contractual acquisition arrangements as well as all contractual (from specification to administration) processes and termination of contract. In a narrower definition, the term may also be used to cover only the specification and establishment of contract (Arrowsmith, 1999).

Government Procurement Contract holds a strategic role for the Government in providing services to community. OECD reported Government Procurement Contract makes up $80 \%$ of all commercial goods and services procurements worldwide (2002). Government Procurement Contract domination may also be seen from the valuation of goods and services expenditure and capital expenditure budgets in Indonesia with significant increase from time to time as suggested in Table 1.

Table 1. Indonesia State Budget for Goods/Services Expenditure and Capital Expenditures for 2010 to 2013

\begin{tabular}{|c|c|c|c|c|}
\hline & 2010 & 2011 & 2012 & 2013 \\
\hline Description & $\begin{array}{ll}\text { Government } & \\
\text { Procurement } & \text { Policy } \\
\text { Board (LKPP) } & \\
\end{array}$ & $\begin{array}{l}\text { Government } \\
\text { Procurement } \\
\text { Board (LKPP) }\end{array}$ & $\begin{array}{l}\text { Revised State Budget } \\
\text { (APBN-P) }\end{array}$ & $\begin{array}{l}\text { State } \\
\text { Budget } \\
\text { (APBN) }\end{array}$ \\
\hline $\begin{array}{ll}\text { 1. } & \text { Goods/Services } \\
\text { Expenditure }\end{array}$ & $97,596.8$ & $124,639.5$ & $162,012.3$ & $200,735.2$ \\
\hline 2. $\quad$ Capital Expenditure & $80,287.1$ & $117,854.5$ & $176,051.4$ & $184,363.5$ \\
\hline
\end{tabular}

Source: Central Government Financial Statements (LKPP) Ministry of Finance RI, 2013.

The government procurement contract has both economical and non-economical (secondary or additional) purposes. In economic perspective, an efficient procurement must consider the value for money to optimize the already limited resources (Cheong May Fong, 2014). To achieve its economical and noneconomical purposes, the Government Procurement Contract must be conducted by adhering to the principles of value for money, fair competition, transparency, accountability, and effectiveness (UN: 2006, Victorian Local Government: 2013). These principles are influence by World Trade Organization (WTO) international best practice and Good Corporate Governance (GCG) principles that include efficient, effective, transparent, open, competitive, fair/non-discriminative, accountable qualities. 
The implementation of these principles is exceedingly hard to achieve especially when practiced in developing countries such as Indonesia. Similar to other Southeast Asian countries (except for Singapore), Indonesia encounters various obstacles in conceptualizing effective Government Procurement Contract due to fragmentation and ambiguity in the regulation and procedures of the contract, which in turn triggers inconsistency, confusion, and lack of accountability (David S. Jones, 2007). Indonesia's weaknesses in the implementation of Government Procurement Contract receive concerns from the World Bank in which in its 2011 Annual Report was stated, "many laws and decisions and regulations are the source of confusion with the risk of overlapping jurisdiction aggravated by inconsistency and lack of clarity in important policy and procedural requirements" (World bank, 2001, pp. 1,9).

To present day, the World Bank's 2001 record cannot be properly addressed. The regulation on the imposition of sanction to violations in goods and services procurement remains obscure. Violations in relation to good and service procurement may come as administrative, civil, or criminal offence. In reality, violations in this area are practically considered as criminal acts on the grounds that the violations have inflicted loss in State finances thus meeting the corruption element as regulated in Articles 2 and 3 of Law No. 20 of 2001 on Amendment of Law No. 31 of 1999. The element of "inflicting loss to state finance" becomes a constraint for state apparatus and partners in implementing the Government Procurement Contract in good faith.

This paper will provide the assistance in describing types of violation in Government Procurement Contract as well as the imposition of sanctions for the said violations. The clarity in segregating types of violation and sanction will assist State apparatus in utilizing State finance for the service to the public without any fear or doubt during their execution of duties and responsibilities.

\section{Discussion}

\subsection{Government Procurement Contract Mapping to Quality Characteristic in Indonesia}

As refer to the Government Procurement Contract, it is important to have clear and concise perspective on good governance conduct (GCG) both as refer to the practice and the law (Maria et al 2013). The good conduct or practice of the contract would not be in a doubt of corruption, administrative or civil violations if the law decisions and regulations have a strong stand on how to visualize in its implementation. To simplify the regulations and procedures into quality characteristics are needed to breakdown each important character of the contract into different and independent meaning of practice. A simpler and easier practice to identify the characteristic of the Government Procurement Contract shall able to enhance the confidence level of State finance to deliver better service to the public without any doubt to violate any law action of corruption, administrative or civil.

Quality characteristic is meant to understand the nature of products/services between providing the products/services and receiving the product/services itself. Eight dimensions of product quality management can be used as comprehensive point of view to analyze quality characteristic (Garvin 2012). However, only five characteristics shall equally map to the GCG of Government Procurement Contract. The mapping is as shown in Fig. 1 below;

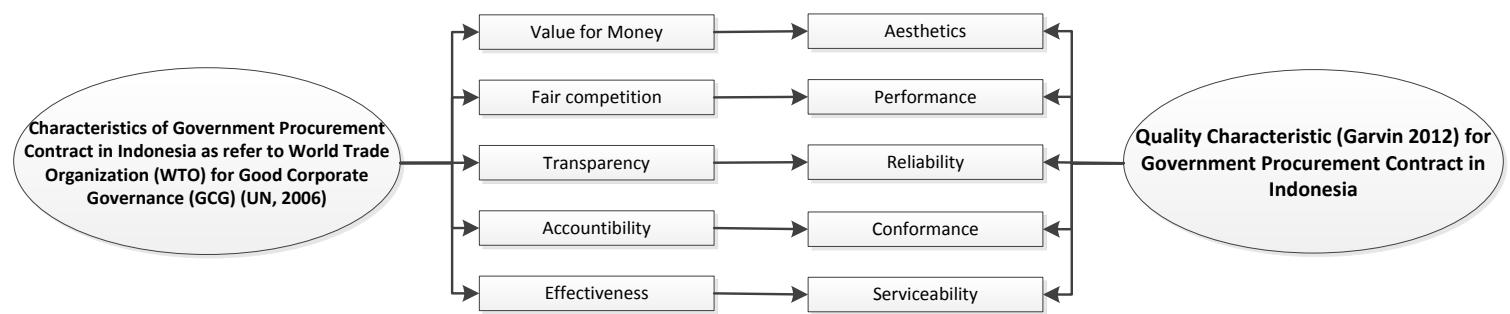

Fig. 1. Government procurement contract mapping to quality characteristic as a comprehensive perspective to simplify and enhance way of practice in Indonesia

The following sub topic will discuss each mapping accordingly to a specific content analysis of regulation and procedures practice in Indonesia. The expected result shall derive clearer and more concise perspective on GCG the practice of the Government Procurement Contract in Indonesia.

1.2. Doubt on the Practice of Administrative/Civil Violation to the Legal Stages in Government Procurement

Various amendments to the Government Procurement Contract regulation do not change the legal aspect in public procurement. The implementation of Government Procurement Contract remains under the administrative law in the processes of preparation, selection, and announcement of the winning bidder. The signing of contract and handover of jobs remain under civil law. 


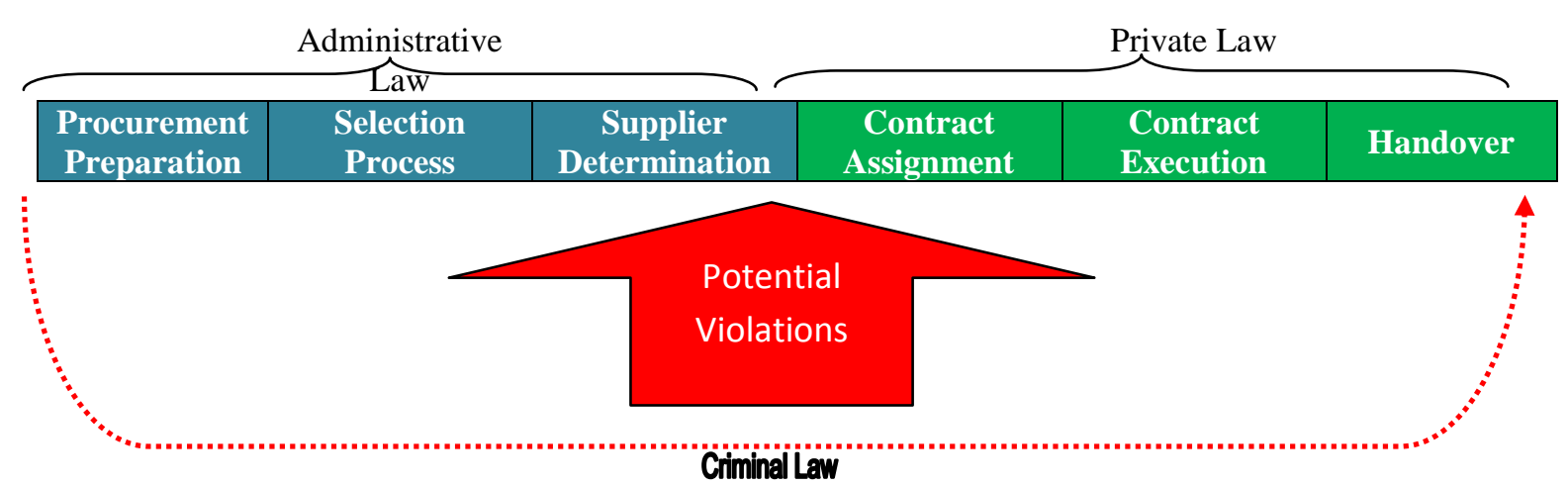

Fig. 2. Legal Stages in Government Procurement

The stage of preparation, selection, and determination of winning bidder is under the scope of administrative law considering Government Procurement Contract implementation is based on the authority mandated by the state to officials as regulated by applicable procedures. Therefore, any violations committed within this stage are considered administrative offence and must receive administrative sanctions.

The stage of preparation, selection, and determination of winning bidder is under the scope of administrative law. However, violations committed in this stage may be subject to administrative, civil, or criminal sanctions. First, administrative violation purely committed by negligence against the procedures and did not inflict any loss to state finance is charged with administrative sanctions such as revocation or cancelation of bidder's requirements. Second, administrative violation committed by negligence against the procedures and inflicted financial losses to the state is charged with civil sanctions as it is considered an unlawful act as regulated in Article 1365 of Indonesian Civil Code. Third, administrative violation committed intentionally and did not inflict any loss to state finance is considered administrative offend, hence is charged with administrative sanctions. Fourth, administrative violation committed intentionally and inflicted financial loss is considered as corruption act. As regulated in Article 3 of Corruption Law, intentional administrative violation is considered an abuse of authority.

The next stage - the signing, execution, and handover of the duty - becomes a part of civil law considering the implementation of this stage is regulated in a contract, hence putting the government and supplier at an equal position as subjects to civil law. Therefore, any breaches of contract are considered civil offence requiring the replacement of costs, loss, and loss interest as regulated in Article 1338 of Indonesian Civil Code. Although the processions of Government Procurement Contract are regulated by administrative and civil laws, potential violations may occur from but not limited to administrative violation and breach of contract. Violations in business competition may occur through conspiracies or unfair business competition at each stage of procurement, hence opening the opportunity for corruptions.

The following sub topic will discuss on how to classify the issues of corruption with regard to the practice of procurement contract. The quality characteristic shall be related to the practice procurement contract for clearer and more conscious stand of action in practice.

\subsection{Doubt on the Practice of Corruption in Government Procurement Contract}

Doubt on the practice of corruption shall bring about an interesting discussion. This study try to elaborate law and quality perspective to provide clearer and more concise point of view to understand for easier and unbiased practice. The discussion comprise of three essential issues with regards to the doubt on the practice of corruption. The first one is to discuss quality characteristics of

1.3.1. Doubt on the Practice of Corruption in the Quality Characteristic of Aesthetics, Performance, and Serviceability

As refer to Figure 1 earlier, three characteristics of GCG, value for money, fair competition, and effectiveness, are equally map to the quality characteristic of aesthetics, performance and serviceability. In product quality management, aesthetics is referring user respond or personal preferences or individual respond to the product/services given from the supplier. Different with the other characteristic, performance consider the user respond to its primary functions/operations. Furthermore to the user's preferences and respond to the primary operations, serviceability concerns more on time handling and effectiveness of delivering the product/services (Garvin 2012). Having the GCG mapping to three quality characteristic as mentioned, this study manage to elaborate through further content analysis of the current regulations and procedures. 
The first discussion is to elaborate of categories of violation of corruption. In Indonesia, corruption becomes a legal offence commonly found in goods and services procurement. However, not all violations in the procurement of goods and services can be categorized as corruption. Under reference of United Nations (2008), it has suggested several categories of violation in public procurement, i.e. (1) Corruption, the act of offering, giving, receiving, or asking both directly and indirectly valuable item(s) to control public officials in selection process or contract assignment; (2) Fraud, an alteration of or negligence in the presentation of actual data to control the selection process or contract assignment; (3) Collusion, an arrangement made by two or more respondents with or without the acknowledgment from procurement institution, designed to establish false or uncompetitive prices; (4) Coercive, the act to injure or threaten, directly or indirectly, people or their properties to control their participation in the procurement process or to control the implementation of a contract. Furthermore, Table 2 below is represented the content analysis of UN categories of violation in public procurement with regard to GCG and quality characteristics respectively.

Table 2 describe clearly that some keywords in the UN categories of violation in Public Procurement can be equally map to the GCG. The practice of GCG in Indonesia then can be simplified to overcome doubt in practice of the violation as mentioned.

The practice of Aesthetics can be found in two content analysis of UN violation categories are No. $1 \&$ 4. As earlier mentioned, Aesthetics is referring user respond or personal preferences or individual respond's to the product/services given from the supplier. User is referring to the government action to evaluate the valuable item accordingly to the government's official standard. The supplier is referring to the public suppliers who enter the process or contract assignment with regard to the procurement contract. Therefore, in the practice of GCG of value for money, both government and public supplier can refer to the practice of Aesthetics. The practice of fulfilling the government's official standard then price comparison shall refer as the government preferences. In addition, the preferences is meant for the ability of the public supplier to fulfill the procurement contract within a competitive price or value for money compare to any others public supplier rather than to control the comparison process.

Table 2. Content Analysis of UN Categories of Violation in Public Procurement to GCG and Quality Characteristics

\begin{tabular}{|c|c|c|c|}
\hline $\begin{array}{l}\text { Content } \\
\text { wording } \\
\text { No. }\end{array}$ & $\begin{array}{l}\text { Content Wording of UN Categories of } \\
\text { Violation in Public Procurement }\end{array}$ & $\begin{array}{l}\text { Violation to Good } \\
\text { Corporate } \\
\text { Governance (GCG) } \\
\text { Characteristics }\end{array}$ & $\begin{array}{l}\text { Simplify Approach to Overcome } \\
\text { Doubt in Practice by Identification } \\
\text { of Quality Characteristics: } \\
\text { Aesthetics, Performance, } \\
\text { \& Serviceability }\end{array}$ \\
\hline 1. & $\begin{array}{l}\text { Valuable item(s) to control public officials in } \\
\text { selection process or contract assignment }\end{array}$ & Value for money & Aesthetics \\
\hline 2. & $\begin{array}{l}\text { To control the selection process or contract } \\
\text { assignment }\end{array}$ & Fair competition & Performance \\
\hline 3. & $\begin{array}{l}\text { An arrangement made by two or more } \\
\text { respondents with or without the } \\
\text { acknowledgment from procurement institution }\end{array}$ & Effectiveness & Serviceability \\
\hline 4. & $\begin{array}{l}\text { Designed to establish false or uncompetitive } \\
\text { prices }\end{array}$ & $\begin{array}{l}\text { Value for money } \\
\text { Fair competition }\end{array}$ & $\begin{array}{l}\text { Aesthetics } \\
\text { Performance }\end{array}$ \\
\hline 5. & $\begin{array}{l}\text { To control their participation in the } \\
\text { procurement process or to control the } \\
\text { implementation of a contract }\end{array}$ & $\begin{array}{l}\text { Effectiveness } \\
\text { Fair Competition }\end{array}$ & $\begin{array}{l}\text { Serviceability } \\
\text { Performance }\end{array}$ \\
\hline
\end{tabular}

Next is the practice of Performance which can be found in No. 2, 4 and 5 of UN categories. Performance considers the user respond to its primary functions/operations. In the procurement contract, the primary function/operations are to have a fair competition in the participation of procurement process and not to control the nature of fair competitiveness. The last practice of quality characteristics is Serviceability which can be seen in No. 3 and 5. Serviceability concerns more on time handling and effectiveness of delivering the product/services. The time handling and effectiveness in the practice of procurement contract is referring the transparency between the government and public supplier. Having open to the other public supplier will increase the time handling and effectiveness of having the right and proper public supplier that match to the procurement contract rather than to initially decide to certain supplier without considering the effectiveness and time handling of the supplier. Initial decision on one supplier will destroy the transparency then lead to inappropriate time handling and ineffectiveness of fulfilling proper procurement contract.

Unfortunately, if UN has identified categories of violation in public procurement, yet Indonesia have not own special regulations in addressing Government Procurement Contract especially under corruption 
categories. Therefore any cases occurred will refer to Law No. 31 of 1999 junc to Law No. 20 of 2001 (hereinafter referred to as Corruption Law). Corruption elements are established in Articles 2 and 3. Corruption elements in Article 2 of the Corruption Law includes (1) every person (2) who against the law (3) enriches himself or other people at a corporation (4) that may inflict losses to state finance or economy. Corruption elements in Article 3 of the Corruption Law includes (1) every person (2) with the purpose to benefit himself or other people at a corporation (3) abuses the authority, opportunity, or facilities available to himself due to title or position (4) that may inflict losses to state finance and economy. Fundamental difference between both articles is that Article 2 contains the element of 'against the law' therefore it is imposable to every person; while Article 3 contains the elements of 'abuse of authority, opportunity, or facilities available due to position' hence applicable only to state apparatus. Based on the regulation, both private parties and state apparatus are subject to law in relation to corruption in public procurement implementation.

The never-ending controversy arises in the element of 'abuse of authority' inflicting state losses. The abuse of authority can be defined as not utilizing the authority as established, therefore can be interpreted as negligence or intentional. This creates a gray area in the imposition of sanction to offenders committing the violation. Such controversy is in need of an ending by drawing a direct correlation between negligence and intentional motives of the abuse of authority.

1.3.2. Doubt on the Practice of Corruption in the Utilization of State Finance for Government Procurement:

Approach on Quality Characteristics of Reliability \& Conformance

According to Garvin (2012), Reliability is a key element for users who need the product/service to work without fail. Furthermore, Conformance is the precision with which the product/service meets the specified standards. Both quality characteristic can respectively map to the GCG characteristic of Transparency and Accountability. In the following discussion, content analysis is done to elaborate the two GCG and quality characteristic with regard to the current practice of regulations and procedures in Indonesia.

In Government Procurement, the funds utilized are sourced from state budget or regional budget. In the scope of State finance, according to Article 1 paragraph 1 of Law No. 1 of 2004 on State Treasury, State losses are defined as the reduction of money, securities, and goods in real and definite amount as a result of unlawful acts, either intentionally or negligently. This indicates that State losses have extensive definition, therefore are understandable and easily upheld when violation against state finance management occurs. In addition, state losses cannot be estimated as desired; the actual value of these losses should be obligatorily calculated. This is intended to create a legal certainty for state finance to impose sanctions to actions inflicting losses to the state.

The legal certainty, as mentioned earlier, can be referring to GCG characteristic of Accountability then map to quality characteristic of Conformance. To simplify the real practice and doubt in corruption on procurement contract, both government and public supplier shall concern to the precision with which the product/service meets the specified standards. Specified standards shall refer to the legal certainty for state finance. State finance shall refer to the state losses. State losses, in this case, do not refer to losses in corporate/commercial scope, but those resulted from the acts against law. In this matter, other factors contributing the state loss include improper implementation of policies and the enrichment of oneself, others, and corporation. This is where state finance officials lose their identities as state apparatus while managing the state finance hence inflicting loss to the state. State losses are the reduction of money, securities, and goods in real and definite amount as a result of unlawful acts, either intentionally or negligently (Djoko Sumaryanto, 2009).

The utilization of state finance is closely related to corruption. Scholars and institutions provide different notions in defining corruption. Nevertheless, these definitions have agreed upon two elements of corruption, i.e. (1) abuse of public authority, and (2) emergence of profit resulted from the abuse of public authority. Sandholtz \& Koetzle define corruption as an abuse of public authority for personal gains (Sandholtz \& Koetzle, 2000). Nye (1978) provides different notion, stating that corruption is a deviation of conduct of formal duties due to personal benefits above the public interests (such as: personal, family, or private group interests) in relation to finance or actions violating an official's code of conduct. World Bank (1997) defines corruption as an abuse of public authority for personal gain. The abuse includes accepting, requesting, or blackmailing for bribery, while private parties offer bribery to avoid public policies to increase competitiveness and gain higher profits. UNDP (2004) defines corruption as abuse of public power, office, or authority for personal interest through bribery, blackmailing, influence, nepotism, fraud, the giving of money to accelerate public official's work process, embezzlement, etc. TI (2002), on the other hand, defines corruption as an illegal conduct of public officials or politicians through the abuse of mandated authority for the benefits of the individual or other related parties. Activities such as irregular money transfer from a person to another person (or from one group to another) and other deviating acts do not receive approval from the Government and are considered illegal.

According to the discussion above, corruption shall relate to the GCG characteristics of Transparency then map to the quality characteristics of Reliability. As refer to the value of Reliability is referring key element 
for users who need the product/service to work without fail. Key element here shall translate as transparency process. The process is referring to abuse of public authority and emergence profit as result from the abuse of public authority. To simplify the practice and doubt in corruption, both government and public supplier may see what the key element is and let the element run well and not fail to work. Such authority abuse is one of cause that let the key element of procurement contract fail to work. Therefore, this practice can be easily identified then can be avoid or much more control to not occurred.

Not only in Indonesia, high international concern on the cases of corruption refers to the fact that corruption threatens the continuity of State's service to the public, in particular in the scope of public procurement. Government Procurement Contract becomes a Government activity most vulnerable to corruption. This condition is worsened in developing countries where lack of transparency and healthy competition also becomes another major concern (OECD: 2004, Thai: 2008). Kuaffman estimated corruption takes 10-25\% of the total Government Procurement Contract budget (Kuaffman, 2007). Kaufman's (2004) estimation of worldwide corruption has reached US $\$ 200$ billion annually. Larger estimations were delivered by Transparency International at a valuation of US $\$ 400$ billion annually. Locally, corruption in Government Procurement Contract shows significant digits, reaching 20\% of total Indonesian public procurement budget. Since 2004, KPK has been solving 107 (38.7\%) of total 283 cases of corruption against Government Procurement Contract. The number is a reminder of the shortcomings in Government Procurement Contract (KPK, 2013).

Involvement with the WTO has changed fundamental policy for Government Procurement Contract in Indonesia. Transparency and non-discrimination has become high concern in the drafting process of a Presidential Decree regulating the public procurement. The Presidential Decree No. 18/2000 was a milestone as for the first time Indonesia finally owns a system especially established for regulating Government Procurement Contract, apart from the State Budget. Presidential Decree No. 18/2000 adopts the principles of Government Procurement Contract designed by UNICITRAL: transparency and non-discriminative principles. The initial Regulation on Government Procurement Contract was then amended by Presidential Decree No. 80/2003 on Government Procurement Contract prepared based on procurement process flow. The Presidential Decree No. 80/2003 was then amended by Presidential Regulation No. 54 of 2010 and recently amended by Presidential Regulation No. 70 of 2012 considering efficient state expenditure and healthy competition were nonexistent in previously-existing Government Procurement Contract. The recent amendment also simplifies the regulation, system, method, and procedures of public procurement while adhering to good governance principles to create efficiency and healthy competition.

\subsubsection{Doubt on the Practice of Corruption: Government Procurement Contract Cases Handling in Indonesia}

Central Jakarta District Court Verdict on corruption case No. 01/PID.B/TPK/2004/PN.JKT.PST dated March 28, 2005 with defendant Ir. H. Abdullah Puteh, M.Si, Governor of Nanggroe Aceh Darussalam began with intentional administrative violation inflicting state losses in the procurement of helicopter by Abdullah Puteh (Governor of Nanggroe Aceh Darussalam in 2001-2003). During the period, Aceh did not make any budget for the purchase of helicopter and Abdullah Puteh has abused his power as a Governor to obtain purchasing fund by cutting the budget of each municipality/city in the Province to generate Rp 9,100,000,000 (nine billion one hundred million Rupiah). The payment for the helicopter was performed in installments. The helicopter was then handed over in 2003 following the completion of the payment. Budget cutting for each municipality/city inflicted financial loss for consecutive municipality/city that was also part of the state finance. Abdullah Puteh was sentenced guilty of committing corruption act in 2005. Apart from inflicting loss to state finance, he also committed the breach of Procurement contract by processing the goods/services procurement and performing the handover of goods despite of the lack of fund.

Jakarta High Court Verdict No. 13/PID/TPK/2008/PT.DKI dated January 21, 2009 with defendant Drs. Abdillah, Ak.,MBA Mayor of Medan City is an example of corruption act inflicting direct losses to the state. Abdillah (Mayor of Medan City) and Ramli (Deputy Mayor of Medan City) were involved in the corruption case of fire truck procurement in 2005-2006. On March 2005 Abdillah and Ramli met with Hengky Samuel Daud (Supplier) to make an agreement on the procurement of a unit of fire truck amounting at $\mathrm{Rp}$ 11,998,875,000 (market price Rp 9,000,000,000) regardless the unavailability of fund. In March the fire truck was handed over, while the payment would be performed later through Revision of Regional Budget 2005 amounting at Rp 9,000,000,000 while the remaining installment would be completed in Regional Budget 2006. Abdillah as the Mayor of Medan City has abused his authority as regional financial manager with his approval of fire truck procurement as it was not included in Regional Budget. This official has also agreed upon the beyond-the-markup price. This abuse of authority committed by Abdillah has inflicted loss in state finance in which the Revised Regional Budget must pay for the unfair price of the fire truck.

Both cases show that goods and services procurement was performed, regardless the unavailability of budget and contract. These actions are violations potential in inflicting losses to the state while not adhering to applicable regulations on state finance and government procurement. 


\section{Conclusion}

Intention in abusing the authority and State finances losses are several characteristics of corruption in public procurement. A violation cannot be considered as corruption when both characteristics do not occur. The abuse of authority due to negligence without inflicting loss to the State is considered as administrative offence thus requiring administrative sanction; while loss-inflicting negligence is considered an offence in civil area. On the other hand, intentional abuse of authority without inflicting loss to the State is categorized as administrative offence instead of the act of corruption.

Good Corporate Government (GCG) and Quality characteristic shall be well integrated to solve doubt in practice of procurement contract in Indonesia. The conflicting of violence categories of corruption or administrative/civil can be reduce by having clearer and more concise point of view of practice. Five proposal of GCG mapping to Quality characteristic shall bring about a comprehensive way of act to the government and public supplier in Indonesia. Five characteristic of GCG are value for money, fair competition, transparency, accountability, and effectiveness then equally map to Quality characteristics of aesthetics, performance, reliability, conformance, and serviceability respectively.

A simpler and more concise point of view of practice shall reduce or even eliminate the doubt of both government and public supplier in the violence categories of corruption or administrative/civil. The improvement of confidence level of practice shall reflect in the quality and fair competitiveness enhancement of GCG in the Government Procurement Contract in Indonesia.

\section{Acknowledgments}

This paper is presented in Workshop and Coaching on Writing Publication in International Journal (WCWPIJ) 2014, Malaysia. Therefore, the authors express their gratitude to ThinkSmart Scholar (TS Scholar) for the event and Assoc. Prof. Dr. Azimon Abdul Aziz from Universiti Kebangsaan Malaysia for the valuable inputs during the preparation and improvement processes of this article.

\section{References}

[1] Benon C. Basheka, Economic and political determinants of public procurement corruption in developing countries: An empirical study from Uganda, Journal of Public Procurement, 11(1), 2011.

[2] Central Jakarta District Court Verdict No. 01/PID.B/TPK/2004/PN.JKT.PST, March 28, 2005.

[3] Cheong May Fong, Goals of public procurement: A fine balancing act for Malaysia, Journal of Malaysian and Comparative Law, 2014.

[4] Conference of the States Parties to the United Nations Convention against Corruption, Second session, Nusa Dua, Indonesia, 28 January - 1 February 2008.

[5] Corruption Eradication Commission, Annual Report of 2013.

[6] David A Garvin. 2012. Competing on the eight dimensions of quality. Harvard Business Review, 65(5), 1987.

[7] David S. Jones, government procurement contract in Southeast Asia: Challenge and reform, Journal of Public Procurement, 7(1), 2007, 3-33.

[8] Djoko Sumaryanto, Pembalikan Beban Pembuktian Korupsi (Bagian III), 2009.

[9] E. Osei-Tutu, E. Badu and D. Owusu-Manu, Exploring corruption practices in public procurement of infrastructural projects in Ghana, International Journal of Managing Projects in Business, 3(2), 2010, 236 - 256.

[10] Emmanuel Obuah, Combating corruption in a "failed" state: The Nigerian economic and financial crimes commission (efcc), Journal of Sustainable Development in Africa, 12(1), 2010.

[11] Indonesian Civil Code.

[12] Jakarta High Court Verdict No. 13/PID/TPK/2008/PT.DKI, January 21, 2009.

[13] Joseph K. Achua, Anti-corruption in public procurement in Nigeria: Challenges and competency strategies, Journal of Public Procurement, 11(3), 2011, 323-353.

[14] K.V. Thai, Measuring losses to government procurement contract corruption: the Uganda case, The 3rd International Government Procurement Contract Conference Proceedings, 28-30 August 2008.

[15] Law No. 5 of 1999 on the Prohibition of monopolistic practices and unfair business competition.

[16] Law No. 31 of 1999 on the Eradication of Criminal Acts of Corruption Law No. 20 of 2001 on Amendment of Law No. 31 of 1999 on the Eradication of Criminal Acts of Corruption.

[17] Law No. 1 of 2004 on State Treasury.

[18] Kalubanga Matthew, Kakwezi Patrick, and Kayiise Denis. The effects of fraudulent procurement practices on government procurement contract performance. International Journal of Business and Behavioral Sciences, 3(1), 2013.

[19] Maria de la Cruz Pulido-Fernandez, Yaiza Lopez-Sancez, Juan Ignacio Pulido-Fernandez, Methodological proposal for the incorporation of governance as a key factor for sustainable tourism management: The case of Spain, International Journal of Humanities and Social Science, 3(15), 2013.

[20] Ministry of Finance of the Republic of Indonesia, (State Budget Ratification), 2013.

[21] UN, UN Procurement Practitioner's Handbook, 2006.

[22] Victorian Local Government, Best Practice Procurement Handbook, 2013.

[23] Sue Arrowsmith, Government Procurement in the WTO, School of Law, University of Nottingham, London: Kluwer Law International, 2003.

[24] Sue Arrowsmith, The Law of Public and Utilities Procurement (London: Sweet \& Maxwell, 1996). 